\title{
An IGF-1 Levels Decrease in SOPK-RI Model Mice After A Low-Carb Diet
}

\author{
Ermawati $^{*}$, Budi Santoso ${ }^{1}$, Widjiati $^{2}$, Hany Puspita Aryani ${ }^{1}$ \\ ${ }^{1}$ Faculty of Medicine, Airlangga University \\ ${ }^{2}$ Faculty of Veterinary Medicine, Airlangga University \\ ermannia@ymail.com
}

\begin{abstract}
Polycystic Ovary Syndrome (PCOS) is a multifactorial endocrinopathy that is common in women. Women with PCOS often experience metabolic disorders including insulin resistance. Insulin resistance leads to hyper-insulinemia which can increase androgen production in ovary and cause hyper-androgenism, this is associated with an increase in the concentration of Insulin-Like Growth Factor (IGF-1). The aim of this study is to analyze the IGF-1 levels decrease in mice modeled by Polycystic Ovary Syndrome Insulin Resistance (SOPK-RI) post carbohydrate high in protein. This study is a True Experimental Design with a Posttest Control Group Design research using 36 tails, female Wistar Rattus Norvegicus Strains, 3 months, 100-200 grams and randomly divided into 3 groups, namely $\mathrm{K}-(\mathrm{n}=12$, negative control group $), \mathrm{K}+(\mathrm{n}=12$, positive control group) and KP ( $\mathrm{n}=12$, treatment group). SOPK-IR modeling is done by mice in the injection of the hormone testosterone provionate at a dose of $100 \mathrm{mg} / \mathrm{kg} \mathrm{BW}$ for 28 days, on the last day after injection a vaginal swab is performed to identify the condition of diestrus. The measurement of IGF-1 levels used the Enzyme-Linked Immunosorbent Assay (ELISA) method. Data analysis techniques used ANOVA test and LSD post hoc test with the Statistical Package for Social Science (SPSS). The results obtained mean levels of IGF-1 at $\mathrm{K}-(234.126 \pm 32.568) \mathrm{ng} / \mathrm{mL}, \mathrm{K}+(169.662 \pm 30.150) \mathrm{ng} / \mathrm{mL}, \mathrm{KP}(146.528 \pm 29.562)$ $\mathrm{ng} / \mathrm{mL}(\mathrm{p}=0.000)$. Based on the results of the study it was concluded that there was a decrease in IGF-1 levels in SOPK-RI mice model after the low-carbohydrate and highprotein diet.
\end{abstract}

Keywords: IGF-1 levels, Insulin Resistance, Polycystic Ovary Syndrome 


\section{STRADA Jurnal Ilmiah Kesehatan}

DOI: $10.30994 /$ sjik.v9i2.298

ISSN: 2252-3847 (print); 2614-350X (online)

Vol.9 No.2 November 2020 Page.325-331

\section{BACKGROUND}

Polycystic Ovary Syndrome (PCOS) is a multifactorial endocrinopathy that is common in women, affecting 10\% - 15\% women in reproductive age (Eleni et al., 2018). PCOS is also related to hormonal disorders that affect the health of women in reproductive age and cause infertility (Azziz, 2016). Women with PCOS often experience metabolic, cardiovascular, type 2 diabetes mellitus, dyslipidemia, visceral obesity and risk of endothelial dysfunction. Therefore, PCOS is not only a fertility problem but also a major health problem that can shorten a woman's life expectancy (Guo et al., 2016).

The etiology underlying PCOS is still unknown but it is possible to have a strong correlation with insulin resistance (Firmansyah et al., 2018). Insulin resistance and hyperinsulinemia occur in 50-75\% of PCOS sufferers and show peripheral insulin resistance similar to type 2 diabetes mellitus. Insulin resistance leads to hyper-insulinemia which can increase androgen production in the ovary and result in hyper-androgenism, this is also associated with an increase in insulin concentration Like Growth Factor (IGF-1) (Ibanez et al., 2017; Hestiantoro and Natadisastra 2013).

IGF-1 is also referred to as somatomedin C, largely synthesized in the liver and regulated by $\mathrm{GH}$ which has a major role in cell growth, cell development and metabolism (Guo et al., 2020; TaeHo Kim et al., 2015). In addition, IGF-1 also has a role in increasing insulin sensitivity and maintaining glucose homeostasis (Haywood et al., 2019). Insulin and IGF-1 signaling involves many regulatory points that are controlled both positively and negatively to ensure the correct duration and intensity of the signal. Disruption in this signaling pathway can cause insulin resistance (Boucher et al., 2014). Studies that conducted by the National Health and Nutrition Examination Survey (NHANES) III, reported an increased risk of insulin resistance, Metabolic Syndrome (MetS) and type-2 diabetes mellitus in subjects with high serum IGF-I concentrations (Friedrich et al., 2012) . Insulin works to produce androgens in the ovary through the IGF-1 receptor (Firmansyah et al., 2018). The involvement of the IGF system as a regulator of intraovarian folliculogenesis is also intensively studied in various mammalian species, it is known that the ovary is the site of expression and reception for IGF-I gene (Aguirre et al., 2016).

Lifestyle modification is recommended as first-line therapy in PCOS before medical therapy which includes dietary interventions by regulating nutritional intake and physical activity (Lin et al., 2019). Nutritional regulation includes foods with a glycemic index and lower glycemic load by modifying the amount of carbohydrates, fats and proteins. Definitive guidelines on diet in women with PCOS have not been developed to date, based on recommendations from the Reproductive Medicine American (RMA) diet that is recommended to limit intake with a $40 \%$ carbohydrate composition, $30 \%$ protein and $30 \%$ fat in line with the diet zone has been shown to successfully increase glucose profiles, insulin and lipids in the population of Type 2 Diabetes Mellitus (Czyżewska-Majchrzak et al., 2014). When carbohydrate intake is limited, it is hoped that it can reduce insulin levels, increase metabolism, accelerate fat oxidation, improve lipid profile and stabilize the action of insulin. The addition of protein intake can significantly increase satiety to reduce body weight, Body Mass Index (BMI), waist circumference and total body fat, thus potentially increasing insulin sensitivity (Gower and Goss, 2015).

Low-carbohydrate-high-protein (RKTP) diets in PCOS with insulin resistance need to be proven in the effectiveness improving metabolic and endocrine systems, therefore more specific research needs to be done as recommendations for proper management of PCOS in terms of dietary intake modification. Based of this, the study aims to analyze the 


\section{STRADA Jurnal Ilmiah Kesehatan}

DOI: $10.30994 /$ sjik.v9i2.298

ISSN: 2252-3847 (print); 2614-350X (online)

Vol.9 No.2 November 2020 Page.325-331

decrease in IGF-1 levels in SOPK-RI mice in the post-diet with low carbohydrate and high protein.

\section{METHODS}

This study is a True Experimental Design with a Posttest Control Group Design research design using 36 tails, female Wistar Rattus Norvegicus Strains, 3 months, 100200 grams and randomly divided into 3 groups, namely $\mathrm{K}-(\mathrm{n}=12$, negative control group ), $\mathrm{K}+(\mathrm{n}=12$, positive control group) and $\mathrm{KP}(\mathrm{n}=12$, treatment group). All research procedures have been approved by the Research Ethics Commission (Animal Care and Use Committee) Faculty of Veterinary Medicine, Airlangga University number 2.KE.062.04.2019.

Modeling Polycystic Ovary Syndrome (PCOS) accompanied by insulin resistance (RI) by mice in the injection of the hormone testosterone provionate at a dose of 100 $\mathrm{mg} / \mathrm{kg} \mathrm{BW}$ for 28 days, on the last day after injection a vaginal swab was performed to identify the condition of diestrus.

The KP intervention was carried out by means of mice in injection of testosterone propionate for 28 days and fed the RKTP diet (K40\% -P30\% -L30\%) for 20 days. The K+ intervention was carried out by means of mice on testosterone propionate injection for 28 days, given a standard diet for 20 days, while giving intervention to $\mathrm{K}$ - by means of mice on placebo injection for 28 days and given a standard diet for 20 days.

Blood was carried out from the left ventricle of experimental animals as much as 2 $\mathrm{ml}$. Blood was done 24 hours after the last high-carbohydrate low-protein diet. Blood was centrifuged for 10 minutes at $3000 \mathrm{rpm}$. The serum was separated and stored at $-80{ }^{\circ} \mathrm{C}$ for analysis of IGF-1 levels the following day. The measurement of IGF-1 levels used the Enzyme-Linked Immunosorbent Assay (ELISA) BT-E0709Ra kit (Biossay Technology Laboratory, Inc., China, 2019) with a standard curve range of 3-900 ng/mL and the sensitivity level of IGF-1 $1.55 \mathrm{ng} / \mathrm{mL}$.

Statistical analysis used Packet Statistics For Social Science (SPSS) software (Chicago, IL, USA). The normality test uses the Shapiro-Wilk test, while the homogeneity test uses the Levene test. Data that are normally distributed and have a homogeneous variant are tested using the ANOVA test and continued with the post hoc LSD test with a significant level $(P<0.01)$. All data are displayed with mean \pm SD.

\section{RESULTS}

The results of the average data analysis of IGF-1 levels after a low-carbohydratehigh-protein diet for 20 days can be seen in Table 1 .

Table 1. Average IGF-1 Levels in Each Group

\begin{tabular}{cccc}
\hline Group & $\mathrm{n}$ & Mean $\pm \mathrm{SD}(\mathrm{ng} / \mathrm{mL})$ & $\begin{array}{c}\text { ANOVA } \\
p \text {-value }\end{array}$ \\
$\mathrm{K}-$ & 12 & $234.126 \pm 32.568^{\mathrm{a}}$ & \\
$\mathrm{K}+$ & 12 & $169.662 \pm 30.150^{\mathrm{b}}$ & $0.000^{*}$ \\
$\mathrm{KP}$ & 12 & $146.528 \pm 29.562^{\mathrm{b}}$ & \\
\hline
\end{tabular}

Note: Different superscripts indicate that there are significant differences in the LSD post hoc test with $(P<0.01)$.

Based on Table 1 it can be seen that the mean IGF-1 levesl in KP is lower compared to $\mathrm{K}+$ and $\mathrm{K}-$. Based on ANOVA test results showed that there were significant differences in the mean levels of IGF-1 $(\mathrm{p}=0.000)$. Based on the post hoc LSD test results showed that there were significant differences in the mean IGF-1 levels between KP with 


\section{STRADA Jurnal Ilmiah Kesehatan}

DOI: $10.30994 /$ sjik.v9i2.298

ISSN: 2252-3847 (print); 2614-350X (online)

Vol.9 No.2 November 2020 Page.325-331

$\mathrm{K}-(\mathrm{p}=0.000), \mathrm{K}+$ with $\mathrm{K}-(\mathrm{p}=0.000)$, whereas $\mathrm{KP}$ with $\mathrm{K}+$ there is no significant difference $(\mathrm{p}=0.075)$, but based on the mean value of IGF-1 levels in $\mathrm{K}+$ tends to be higher than the average value of KP.

\section{DISCUSSION}

Based on ANOVA test results showed that there were significant differences in the mean IGF-1 levels in PCOS. These results are likely due to the interventions provided. It is because in each group there are differences in the administration of the intervention even though all samples in the 3 groups both experienced PCOS and insulin resistance. PCOS is the most common endocrine disorder in women that affects every aspect of a woman's life by around 6-10\%, including reproductive, mental, cardiovascular, and metabolic health (Meier, 2018). PCOS is a collection of symptoms of amenorrhea, oligomenorrhea, infertility, obesity, hirsutism, acne, alopecia and acanthosis nigrikan. Of all women in reproductive age spread throughout the world, $4-18 \%$ of them experience PCOS. PCOS causes 5-10\% of women in reproductive age to become infertility (Mareta et al., 2018). PCOS is also said to be an androgen or hyper-androgen excess disorder. When experiencing hyper-androgen can affect IGF-1 expression (Susanto et al., 2012). PCOS has decreased sensitivity to insulin, moreover it is modeled to have insulin resistance. Because of PCOS modeling and insulin resistance in this study, the decrease in insulin sensitivity is higher. According to Bremer and Miller (2008) said that decreased insulin sensitivity in PCOS depends on the degree of adiposity, fat topography and androgen levels. However, PCOS patients with insulin resistance usually do not experience structural abnormalities in the insulin receptor, a decrease in the number of insulin receptors (RI), or changes in insulin binding affinity. Thus, a post-receptor mechanism is very likely to be responsible. In addition, Susanto et al. (2012) added that hyper-androgen in PCOS model causes an increase in insulin resistance index, possibly caused by post receptor defects resulting in hyper-insulinemia. This condition will cause an increase in IGF-1 expression. Increased IGF-1 expression will cause IGF-1 receptors also increase. In addition, hyper-androgens also affect increased levels of free estrogen in the endometrium. This increase in PCOS is caused by free estrogen which increases in the peripheral and endometrium due to changes in enzymes in the endometrial lining. Estrogen binding and estrogen receptors cause increased proliferation and decreased apoptosis in the endometrium. Besides that, estrogen and estrogen receptor binding can activate IGF-1 receptors without ligands. While due to modeling of insulin resistance can cause hyper-insulinemia as an insulin insensitivity compensation reaction. High levels of insulin will stimulate ovarian androgen production by various mechanisms. Hyperinsulinemia will inhibit liver secretion in producing Insulin Like Growth Factor Binding Protein-I (IGFBP-I) and increase IGF-1.

Based on Table 1 the results of the post hoc LSD test showed that there are significant differences in the mean IGF-1 levels between KP and K-. KP is the treatment of a diet low in carbohydrates and high in protein, whereas in $\mathrm{K}+$ by placebo injection, the treatment in this group affects the state of PCOS. The results in this study are in line with the results of research conducted by Irene (2019), concluding that calorie intake, consumption of carbohydrates, protein, fat and fiber consumption affect the PCOS conditions. Likewise, the study of Zhang et al., (2019) explained that a low-carbohydrate diet is good for PCOS patients. IGF-1 levels in KP are lower than in $\mathrm{K}+$, this is likely due to $\mathrm{K}+$ experiencing weight gain, but $\mathrm{KP}$ is given a low carbohydrate and high protein treatment so that it tends to have a more stable body weight. Based on research shows that the prevalence of PCOS is higher in overweight, obese women and up to $30 \%$ of women who have a BMI $>30 \mathrm{~kg} / \mathrm{m}^{2}$ meet the diagnostic criteria of PCOS (Boyle et al., 2012). 


\section{STRADA Jurnal Ilmiah Kesehatan}

DOI: $10.30994 /$ sjik.v9i2.298

ISSN: 2252-3847 (print); 2614-350X (online)

Vol.9 No.2 November 2020 Page.325-331

Overweight affects subfertility in a woman and can affect the reproductive organs that cause irregular menstruation, subfertility, Polycystic Ovary Syndrome (PCOS), uterine cancer, endometrium, breast and cervix. Weight gain is followed by an increase in insulin and Insulin Like Growth Factor-1 (IGF-1). This can affect the situation in the uterus so that it can result in the failure of the fertilization process (Chavarro et al., 2008). In addition, weight gain experienced by $\mathrm{K}+$ can also further increase insulin resistance and hyper-insulinemia. Insulin works directly in the ovary by stimulating testosterone biosynthesis. Insulin also inhibits the production of SHBG in the liver, so that it will produce an increase in free testosterone levels. Free testosterone levels can induce abdominal fat accumulation and insulin resistance. Then the result can be a continued increase in body weight and worsen the symptoms of reproductive and metabolic PCOS (Hirschberg, 2009). Therefore, the effect of increasing body weight on $\mathrm{K}+$ can worsen metabolism in PCOS characterized by higher IGF-1 levels than KP. KP given a diet low in carbohydrates and high in protein so that it can reduce IGF-1 levels. This is supported by the explanation of Guzick (2004) that weight loss in PCOS is beneficial for reducing levels of androgen hormones, Luteinizing Hormone (LH) and insulin levels, so that it can help regulate ovulation regulation in women.

Based on the post hoc LSD test it was found that $\mathrm{KP}$ with $\mathrm{K}+$ there were no significant differences, but based on the mean value of IGF-1 levels in $\mathrm{K}+$ tended to be higher than the average value of KP. The results showed that $\mathrm{K}+$ tends to be higher in line with previous research that Susanto et al. (2012) that by giving testosterone to patients with PCOS can increase the amount of expression of IGF-1 and endometrial glands. IGF-1 levels are higher in $\mathrm{K}+$, possibly due to $\mathrm{K}+$ given testosterone injection so that hyperandrogens occur, besides that $\mathrm{K}+$ also has hyper-insulinemia. The state of hyper-androgens is related to hyper-insulinemia (Mareta et al., 2018). Hyper-androgens can cause insulin resistance. The administration of testosterone to the endometrium causes a significant decrease in the expression of IRS-1 and GLUT-4 in glandular epithelial cells. This proves that high androgen levels cause insulin resistance in the endometrium. In addition, hyperandrogen in the PCOS model can affect the insulin resistance index and the level of free fatty acids in serum. Hyper-androgens can affect the expression of IGF-1 in the endometrium resulting in endometrial proliferation and hyper-plasia. Prolonged androgen exposure results in increased expression of IGF-1 in the endometrium and results in endometrial proliferation and hyper-plasia (Susanto et al., 2012). Hyper-insulinemia causes theca cells actively produce androgens, so free androgens increase (Mareta et al., 2018) and cause IGF-1 BP levels to decrease, followed by an increase in IGF-1 (Speroff and Fritz, 2005). The excess insulin will be bound by IGF-I which works on theca cells to increase LH levels. Insulin will also activate the serine phosphorylation pathway which can increase the activity of P450c17 in the ovaries and adrenals which will stimulate androgen synthesis. Insulin also suppresses levels of Sex Hormone Binding Globulin (SHBG) so that free androgen levels increase. High levels of androgens will interfere with the aromatase system in granulosa cells, leading to early follicular atresia (Balen et al., 2005; Speroff and Marca, 2011).

\section{CONCLUSION}

Based on the results of the study, it is concluded that feeding a low-protein highcarbohydrate (RKTP) diet (K40\% -P30\% -L30\%) for 20 days significantly reduced IGF-1 levels in polycystic ovary syndrome mice models accompanied by insulin resistance (SOPK-RI) compared with negative control and positive control. 


\section{STRADA Jurnal Ilmiah Kesehatan}

DOI: $10.30994 /$ sjik.v9i2.298

ISSN: 2252-3847 (print); 2614-350X (online)

Vol.9 No.2 November 2020 Page.325-331

\section{REFERENCES}

Aguirre, G.A., De Ita, J.R., and de la Garza, R.G. 2016. Insulin-Like Growth Factor-1 Deficiency and Metabolic Syndrome.J Transl Med 14:3. https://doi.org/10.1186/s12967-015-0762-Z.

Azziz, R., Carmina, E., Chen, Z.J., Dunaif, A., Laven,J.S.E., Legro, R.S. 2016. Polycystic ovary syndrome.Nature Reviews Disease Primers, 11(2):1-18. https://doi.org/10.1038/nrdp.2016.57. PMID: 27510637.

Balen, H.A., Gerrard, S.C., Roy, H., Richard, S.L. 2005. Polycystic ovary syndrome: a guide to clinical management. Francis: CRC Press.

Boucher, J., Kleinridders, A. and Kahn, C.R. 2014. Insulin receptor signaling in normal and insulin-resistant states. Cold Spring Harbor perspectives in biology, 6(1):a009191. https://doi.org/10.1101/cshperspect.a009191.

Boyle, J.A., Cunningham, J., O’Dea, K., Dunbar, T., Norman, R.J. 2012. Prevalence of polycystic ovary syndrome in a sample of Indigenous women in Darwin, Australia. Med J Aust, 196:62-68. https://doi.org/10.5694/mja11.10553.

Bremer, A.A. and Miller, W.L. 2008. The Serine Phosphorylation Hypothesis of Polycystic Ovary syndrome: a Unifying Mechanism for Hyperandrogenism and Insulin resistance. Fertility and Sterility, 89:1039-48. https://doi.org/10.1016/j.fertnstert.2008.02.091.

Chavarro, J.E., Rich-Edwards, J.W., Rosner, B.A. and Willett, W.C. 2008. Use of multivitamins, intake of $\mathrm{B}$ vitamins, and risk of ovulatory infertility. Fertility and Sterility, 89(3): 668-676. https://doi.org/10.1016/j.fertnstert.2007.03.089.

Czyżewska-Majchrzak, L., Grzelak, T., Kramkowska, M., Czyżewska, K., Witmanowski, H. 2014. The use of low-carbohydrate diet in type 2diabetes - benefits and risks.Ann Agric Environ Med,21(2):320-326. https://doi.org/10.5604/12321966.1108597.

Eleni, A.G., Lauri, A.P., Marcelle, I., Richard, S. L., Esther, E. and Heather, G. 2018. Insulin Resistance Is Associated WithDepression Risk In PolycysticOvary Syndrome. Fertility and Sterility, 110(1):27-34. https://doi.org/10.1016/j.fertnstert.2018.03.009. PMID: 29908775. PMCID: PMC6392023. Epub 2018/06/13.

Firmansyah, A., Chalid, M.T., Farid, R.B. and Nusratuddin, N. 2018. The correlation between insulin-like growth factor binding protein 1 (IGFBP-1) and homeostasis model assessment of insulin resistance (HOMA-IR) in polycystic ovarian syndrome with insulin resistance. International journal of reproductive biomedicine, 16(11):679-682. PMCID: PMC6350850. PMID: 30775682.

Friedrich, N., Thuesen, B., Jørgensen, T., Juul, A., Spielhagen, C., Wallaschofksi, and Linneberg, A. 2012. The Association Between IGF-I and Insulin Resistance. American Diabetes Association: Diabetes Care,35(4): 768-773. https://doi.org/10.2337/dc11-1833.

Gower, B. A., and Goss, A.M. 2015. A lower-carbohydrate, higher-fat diet reduces abdominal and intermuscular fat and increases insulin sensitivity in adults at risk of type 2 diabetes. The Journal of Nutrition, 145(1):177S-183S. https://doi.org/10.3945/jn.114.195065.

Guo, Y., Qi, Y., Yang, X., Zhao, L., Wen, S., Liu, Y. and Tang, L. 2016. Association between Polycystic Ovary Syndrome and Gut Microbiota. PLoS One, 11(4): e0153196. https://doi.org/10.1371/journal.pone.0153196. 


\section{STRADA Jurnal Ilmiah Kesehatan}

DOI: $10.30994 /$ sjik.v9i2.298

ISSN: 2252-3847 (print); 2614-350X (online)

Vol.9 No.2 November 2020 Page.325-331

Guo, J., Xie, J., Zhou, B., Gaman, M-A., Kord-Varkaneh, H., Clark, C.C.T., SalehiSahlabadi, A., Li, Y, Han, X., Hao, Y. and Liang, Y. 2020. The influence of zinc supplementation on IGF-1 levels in humans: A systematic review and metaanalysis. Journal of King Saud University - Science, https://doi.org/10.1016/j.jksus.2020.01.018.

Guzick, D.S. 2004. Polycystic Ovary Syndrome. Obstet Gynecol, 103(1): 181-193. https://doi.org/10.1097/01.AOG.0000104485.44999.C6.

Haywood, N.J., Slater, T.A., Matthews, C.J. and Wheatcroft, S.B. 2019. The insulin like growth factor and binding protein family: Novel therapeutic targets in obesity \& diabetes. Molecular Metabolism, 19:86-96. https://doi.org/10.1016/j.molmet.2018.10.008.

Hestiantoro, A. and Natadisastra, M. 2013. Current Updates on: Polycystic Ovary Sindrome, Endometriosis, Adenomyosis. Jakarta: Sagung Seto. pp. 1-52.

Hirschberg, A.L. 2009. Polycystic Ovary Syndrome, Obesity and Reproductive Implications. Women's Health, 5(5): 529-542. https://doi.org/10.2217/whe.09.39.

Ibáñez, L., Oberfield, S.E., Witchel, S., Auchus, R.J., Chang, R.J., Codner, E., Dabadghao, P., Darendeliler, F., Elbarbary, N.S., Gambineri, A., Garcia Rudaz, C., Hoeger, K.M., López-Bermejo, A., Ong K., Peña, A.S., Reinehr, T., Santoro, N., TenaSempere, M., Tao, R., Yildiz, B.O., Alkhayyat, H., Deeb, A., Joel, D., Horikawa, R., de Zegher, F., and Lee, P.A. 2017. An International Consortium Update: Pathophysiology, Diagnosis, and Treatment of Polycystic Ovarian Syndrome in Adolescence. Horm Res Paediatr 371-395. https://doi.org/10.1159/000479371.

Irene, A. 2019. Hubungan Pola Makan dengan Resiko Terjadinya Sindrom Ovarium Polikistik pada Remaja Yang Berusia 15-19 Tahun Di Kota Palembang. Skripsi: Fakultas Kedokteran, Universitas Sriwijaya.

Lin, A. W., Kazemi, M., Jarrett, B. Y., Vanden Brink, H., Hoeger, K. M., Spandorfer, S. D., and Lujan, M.E. 2019. Dietary and Physical Activity Behaviors in Women with Polycystic Ovary Syndrome per the New International Evidence-Based Guideline. Nutrients, 11(11): 2711. https://doi.org/10.3390/nu11112711.

Mareta, R., Amran, R., Larasati, V. 2018. Hubungan Polycystic Ovary Syndrome (PCOS) dengan Infertilitas di Praktik Swasta Dokter Obstetri Ginekologi Palembang. $\begin{array}{llll}\text { Majalah } & \text { Kedokteran } & \text { Sriwijaya, } & \text { 50(2): }\end{array}$ https://doi.org/10.36706/mks.v50i2.8552.

Meier, R.K., 2018. Polycystic Ovary Syndrome. Nursing Clinics of North America. https://doi.org/10.1016/j.cnur.2018.04.008.

Speroff, L. and Fritz, M. 2005. Clinical Gynecologic Endocrinology and Infertility. Seventh Edition. Philadelphia: Lippincott Williams \& Wilkins.

Speroff, L. and Marca, A.F. 2011. Clinical gynecologic endocrinology and Infertility. Edisi ke-8. Baltimore. USA: William Lippincot William \& Wilkins.

Susanto, E., Santoso, B., Samsulhadi, Widjiati. Korelasi Jumlah Ekspresi Reseptor IGF-1 (Insulin Like Growth Factor-1) dan Kelenjar Endometrium Rattus norvegicus Strain Wistar Model SOPK (Sindroma Ovarium Polikistik) yang Mendapat Testosteron. Majalah Obstetri \& Ginekologi, 20: 51-57.

TaeHo Kim, Chang, J.S., Kim, H., Lee, K.H. and Kong, I.D. 2015. Intense Walking Exercise Affects Serum IGF-1 and IGFBP3. Journal of Lifestyle Medicine, 5(1):2125. http://dx.doi.org/10.15280/jlm.2015.5.1.21. 